\title{
Employment Policy and Its Implications for Protection of Indonesian Migrant Workers (IMW): A Comparative Study between Hong Kong and Malaysia
}

\author{
Tyas Retno Wulan \\ Department Sociology, Jendral Soedirman University \\ HR Bunyamin Street, Purwokerto Indonesia \\ Faculty of Social and Political Studies Jendral Soedirman University \\ tyashzul@yahoo.com
}

\begin{abstract}
Based on data from the National Agency for the Placement and Protection of Indonesian Workers (BNP2TKI), in 2013 there were about 6, 5 million Indonesian migrant workers (IMW) working in 142 countries around the world, and there are 6 countries which are the favorite host country destination namely Saudi Arabia, Malaysia, Singapore, Hong Kong, Taiwan and the United Arab Emirates. An increased number of IMW working abroad does not mean that they have good protection as well. In 2013 there were approximately 20 thousand cases affecting migrant workers such as job out of contract, underpayment, violence, sexual abuse, death penalty etc. Malaysia is the country which is considered as the most unsafe for IMW, on the contrary, Hong Kong is considered as the most secured and friendly host country for IMW. This study aims to identify policy differences between Malaysia and Hong Kong in treating IMW. The method used in this study is a qualitative method. Informants are migrant workers who are or have worked in Malaysia and Hong Kong. The results shows that Hong Kong has policy named ordinary employment listed in chapter 57 which contains clear and unequivocal rights and obligations of the IMW, meanwhile Malaysia does not have a labor policy that protects the IMW, they even treats IMW discriminatively.
\end{abstract}

Keyword: Employment Policy, Indonesian Migrant Workers, Protection

\section{Introduction}

Based on data from the National Agency for the Placement and Protection of Indonesian Workers (BNP2TKI), in 2013 there were about 6, 5 million Indonesian migrant workers working in 142 countries around the world, and 80 percent of them are women. The economic remittance resulted reached U.S. \$ 6-7 billion per year. Among 142 countries, there are 6 countries which are the favorite host country destination of IMW especially for those who work in the informal sector, namely Saudi Arabia, Malaysia, Singapore, Hong Kong, Taiwan and the United Arab Emirates. However, an increased number of IMW working abroad does not mean that they have good protection as well. In 2013 there were approximately 20 thousand cases affecting migrant workers such as job out of contract, underpayment, violence and sexual abuse, death penalty in the host country, etc. Malaysia is the country which is considered as the most unsafe for IMW, it is showed by many problems faced by IMW who work there. On the contrary, Hong Kong is considered as the most secured and friendly host country for IMW. This fact is very interesting, and urgent to be studied since they are both Asia countries but they have differences in the policies and the protection for IMW. This study aims to identify policy differences between Malaysia and Hong Kong in treating IMW.

\section{Method}

The method used in this study is a qualitative method using in-depth interviewing techniques. Informants are migrant workers who are or have worked in Malaysia and Hong Kong; NGO or IMW organization. A secondary data analysis of the employment policies of both countries is also done to enrich the analysis. 


\section{Analysis and Discussion}

Malaysia is the most destinations desirable country for IMW. For years 2011-2013 , Malaysia became the first rank Country of IMW. Geographically, the proximity of Malaysia to Indonesia and are considered to be relatively the same culture makes many Indonesian citizens choose Malaysia as a destination country for a living, both legally and illegally. Currently about 2.2 million IMW choose Malaysia as a favorite destination . But the actual number is probably much more, because the exact number is difficult to verify. Most of them are undocumented, without a permit or their work visa is not valid. The issue of equality or culture's sameness and more easily work requirements in Malaysia are main attractions for the IMF to work there. Actually, the long history of migration from Indonesia to Malaysia, and cultural equality, did not make the IMW who work at Malaysia devoid of problems. Rather than IMW Country of others, especially Hong Kong, IMW who work at Malaysia are the most frequently plagued by problems, ranging from positioned as " indon " which is interpreted as a second -class society and ignorant, inhuman treatment by troops LIRA, to torture that led to death. Refer to Wulan's study ( 2011) in Wonosobo and Banyumas Central Java shows that Malaysia selected as one of the favorite destinations for very pragmatic reasons : first because the requirements are not difficult, and second, go to Malaysia is a means of " deliberation " or training before go to a country that is more promising as Singapore or Hong Kong. According to the Secretary of the National Central Bureau ( NCB ) - Interpol Indonesia Brigadier General ( Pol ) Halba Rubis Nugroho, every day at least one IMW in Malaysia died due to various reasons. Recorded 1,421 citizens who died in Malaysia in the last three years. The number of citizens who died in quick succession in 2007 recorded 690 people, in 2008 as many as 524 people, and in 2009 recorded 207 people as of August (Kompas, 20 September 2009 ).

In 2009, there was actually an attempt to improve the protection of IMW in Malaysia. Beginning with the moratorium on June 26, 2009 , where the government officially stopped sending informal IMW to Malaysia. This policy was taken following the disclosure of many cases of IMW experienced working in Malaysia (Wulan, 2009). The implication is significant, because Malaysia is willing to sit down together and fix a memorandum of understanding (MOU) with Indonesia . At that time, the proposal contains, among others, IMW Indonesia may hold its own passport, there is a clear job description, salary hikes and transparency, leave, holidays once a week, a fair legal treatment and discipline agents in Malaysia. When the new Malaysian government is willing clause that IMW alone may hold passports as well as law enforcement. During that time the Malaysian government does not provide a framework for the protection of migrant workers. Malaysian Employment Act of 1995 specifically ruled out domestic workers, including regulations on working hours, holidays and termination of the contract. Legal protection is not clear to IMW Indonesia in Malaysia eventually have implications for their chances of gaining social remittances for work in Malaysia. Passport held by the employer makes the IMW does not have freedom of association or union or organization to organize despite IMW in Malaysia. As one of the destination country for IMW, Hong Kong have different policy with Malaysia. Hong Kong has one of the employment objectives set by the Government of 
Indonesia, so year by year, IMW who works to Hong Kong officially done with intensity and the number continues to grow. Currently listed Hong Kong ranks 5th of Country of IMW. Bases on data from the Hong Kong Immigration Department, there were approximately 122,900 current IMW is worked in Hong Kong, with a composition of 99.9 percent were female ( FMW ) and only 0,01 percent of men. IMW who work at Hong Kong have a distinctive character when compared with IMW in Malaysia . One major factor is that the IMW in Hong Kong, has the rights, obligations and standard work contracts arranged by the government of the Hong Kong Employment Ordinance contained in Chapter 57 for foreign domestic helpers or Foreign Domestic Helper . That rules set out clearly the rights of the IMW , among other issues the employment contract is valid for two (2 ) years ; the minimum wage ; job description ; decent living conditions ; accident insurance ; one day off a week ; annual leave for 7 days ; meals and transportation on the way as well as a medical examination if the IMW hospital. So although Indonesia and Hong Kong does not have an agreement ( MOU ) regarding the placement and protection of labor, the Hong Kong Government has consistently applying rules and laws are unfair to the IMW. Although the rights, obligations and the IMW standard employment contract in Hong Kong has been protected with a clear legal framework and a study conducted by researchers not mean there are many problems faced by the IMW in Hong Kong. These problems can be categorized as structural problems and cultural issues. Called structural problems if it is related to government policy and cultural issues are categorized, in the event due to cultural differences Hong Kong and Indonesia as well as the lack of sufficient knowledge of the IMW of the policies and culture in Hong Kong . In addition, the basic problem often encountered is the number of IMW's that do not understand the contents of the contract,; then how to get along excessive, too fast to believe new people and new cultures dissolve facing, so the IMW found some cases like pregnant with stranger man, but finally the man escape. In 2008 for example, the Consulate accommodate and take care of IMW's four babies . According to the migrant workers' organizations and NGOs, the most fundamental issues who complained are problem of underpayment ( salary below the standard ) and the cost structure ( high cost of IMW's placement to Hong Kong which is charged to the IMW of HK \$ 21,000 by way of a salary cut for 7 month.

\section{Conclusion}

Based on analysis of Malaysia and Hong Kong as a Destination Country of IMW there is a substantive difference between Hong Kong and Malaysia. The Malaysia government does not provide a framework for the protection of migrant workers. Malaysian Employment Act of 1995 specifically ruled out domestic workers, including regulations on working hours, holidays and termination of the contract . Unclear legal protection for Indonesian IMW in Malaysia eventually have implications for their protection and chances for gaining social remittances. Passport held by the employer makes the IMW does not have freedom to join association or union or organization to organize despite Indonesian workers in Malaysia . Hong Kong set to detail the rights and obligations expressly IMW in Employment Ordinary Chapter 57. Law governing the rights expressly IMW. This implies a substantial of two things: first that the rights and obligations of IMW relatively well protected than Malaysia and two implications of 
these conditions the IMW is opening opportunities to develop their social remittances in the country of destination .

\section{References}

1) Ecosoc Rights. (2008) Menangani Perbudakan Modern dari Desa: Rancang Bangun Perbudakan Modern dari Desa. Jakarta

2) Human Rights Watch. (2004). 16 (9)

3) Tyas Retno Wulan. (2009).Strategi Pemberdayaan Buruh Migran Perempuan Indonesia di Hong Kong. Jurnal Agrisep Fakultas Pertanian Universitas Bengkulu, 10 (1)

4) _ (2010).Buruh Migran Perempuan Melawan Negara dan Pasar dengan Remitansi Sosial, Jurnal Analisis Sosial Akatiga, Vol 15 No.2 Desember 2010

5) . (2009). Penghentian Pengiriman TKI, Menjadi Solusi atau Masalah. Kompas 20 Nopember

6) Kompas. (2009). Menggugat Kelalaian Negara, 29 Juli 